\title{
Hispolon inhibits breast cancer cell migration by reversal of epithelial-to-mesenchymal transition via suppressing the ROS/ERK/Slug/E-cadherin pathway
}

\author{
ZHAO ZHAO ${ }^{2}$, YI-SHENG SUN ${ }^{1,3}$, WEI CHEN ${ }^{1}$, LONG-XIAN LV $^{1}$ and YONG-QUAN LI ${ }^{1}$ \\ ${ }^{1}$ College of Life Science, Zhejiang University; ${ }^{2}$ Centre of Laboratory Medicine, Zhejiang Provincial People's Hospital; \\ ${ }^{3}$ Zhejiang Provincial Center for Disease Control and Prevention, Hangzhou, Zhejiang, P.R. China
}

Received July 13, 2015; Accepted September 17, 2015

DOI: $10.3892 /$ or.2015.4445

\begin{abstract}
Hispolon has been shown to have anticancer effects on various tumors. However, whether hispolon exerts antimigration activity in breast cancer cells and the underlying mechanisms, have not been elucidated yet. In the present study, our data demonstrated that hispolon inhibited TPA-induced breast cancer MCF-7 cell migration at sub-toxic concentrations in vitro. Hispolon decreased the level of cellular ROS significantly and repressed TPA-induced phosphorylation of extracellular signal-regulated kinase (ERK), accompanied by upregulation of E-cadherin and downregulation of the transcriptional repressor Slug. Furthermore, N-acetyl-cysteine, an antioxidant agent, markedly suppressed TPA-induced epithelial-to-mesenchymal transition, cell migration and activation of ERK. Taken together, our results indicated that hispolon suppressed the migration of breast cancer cells via suppressing the ROS/ERK/Slug/E-cadherin pathway. Hispolon may be developed as a potential antimetastasis agent to breast cancer.
\end{abstract}

\section{Introduction}

Breast cancer is the most frequently diagnosed cancer and the second leading cause of cancer-related deaths among women worldwide (1). The high breast cancer mortality rates are mainly caused by the metastasis of tumor cells (2), which can induce radiation therapy and chemotherapy resistance in advanced breast cancer. Therefore, the therapeutic strategies

Correspondence to: Professor Yong-Quan Li, College of Life Science, Zhejiang University, Hangzhou, Zhejiang 310058, P.R. China

E-mail: lyq@zju.edu.cn

Abbreviations: MAPK, mitogen-activated protein kinase; TPA, phorbol 12-myristate 13-acetate; EMT, epithelial-to-mesenchymal transition; ERK, extracellular signal-regulated kinase AKT, protein kinase B; NAC, N-acetyl-cysteine; ROS, reactive oxygen species

Key words: hispolon, epithelial-to-mesenchymal transition, E-cadherin, reactive oxygen species, extracellular signal-regulated kinase including the development of effective antimetastatic agents have potential benefits for breast cancer treatment.

Growing evidence indicates that the epithelial mesenchymal transition (EMT), a developmental process which involves loss of cell-cell junctions and re-organization of the actin cytoskeleton, resulting in loss of apical-basal polarity and acquisition of a spindle-like mesenchymal morphology, plays an important role in breast cancer metastasis $(3,4)$. E-cadherin, a key factor included in EMT, has been associated with the metastasis process in breast cancer. The loss function of E-cadherin elicits active signals that induce tumor cell migration, invasion and metastatic dissemination $(5,6)$. Moreover, levels of E-cadherin have also been found to correlate with enhanced metastasis and associate with poor prognosis and relapse in breast cancer patients (7). Transcription of E-cadherin is repressed by zinc finger proteins of the Slug/Snail family and Smad-interacting protein $(8,9)$. To date, numerous clinicopathological studies have shown positive correlations between the expressions of the transcription factors Snail and Slug, which are the key inducible factors of EMT, and poor clinical outcomes in breast, ovary, colorectal and lung cancer (10).

Reactive oxygen species (ROS), continuously generated from mitochondrial respiratory chain during intracellular metabolism, are a family of molecules in response to environmental stimuli, including superoxide radical $\left(\mathrm{O}^{2-}\right)$, hydrogen peroxide $\left(\mathrm{H}_{2} \mathrm{O}_{2}\right)$, hydroxyl radical $(\cdot \mathrm{OH})$ and singlet oxygen. Accumulating evidence suggests that ROS are emerging as critical signaling stimuli that mediate a variety cellular functions including cell cycle progression, apoptosis and motility (11-13). ROS signaling pathway has been reported to be intimately involved with EMT in tumor progression $(14,15)$. Various factors such as epidermal growth factor (EGF), hepatocyte growth factor (HGF), insulin-like growth factor (IGF)-I and interleukin-1 $\beta$ (IL-1 $\beta$ ) induce EMT in the progression of tumor cells through ROS generation (16-19). It is also suggested that ROS play an essential role in TPA-induced sustained PKC-ERK activation which is responsible for EMT and migration of HepG2 (20). Another study showed that long-term oxidative stress may induce invasive potential of mammary epithelial cells (21).

Hispolon, a poly-phenol compound, which was first isolated from Inonotus hispidus and has since been isolated from many 
tropical mushrooms $(22,23)$. Previous studies have shown that hispolon inhibits tumor growth and metastasis through various signal pathways $(22,24-26)$. Also we have shown that hispolon-induced apoptosis in human gastric cancer cells through a ROS-mediated mitochondrial pathway $(22,24)$. However, whether hispolon could exert anti-migration activity in breast cancer cells as well as the underlying mechanisms have not been elucidated. In the present study, we found that hispolon inhibited TPA-induced migration of MCF-7 cells by recovering E-cadherin activity. In addition, this effect was dependent on the ROS/p-ERK/slug/E-cadherin related signaling pathway.

\section{Materials and methods}

Materials and cell culture. Transwell chambers were purchased from Corning Costar (USA). Antibodies specific for ERK, phospho-ERK, JNK, phospho-JNK, p38, phosphop38 MAPK, AKT, phosphor-AKT, Snail, Slug and E-cadherin were all purchased from Cell Signaling Technology (Beverly, MA, USA). Human breast cancer MCF-7 cells were maintained in RPMI-1640 medium supplemented with $10 \%$ fetal bovine serum, $100 \mathrm{U} / \mathrm{ml}$ penicillin $\mathrm{G}$ and streptomycin $100 \mathrm{mg} / \mathrm{ml}$, and were incubated at $37^{\circ} \mathrm{C}$ in a humidified atmosphere of $95 \%$ air and $5 \% \mathrm{CO}_{2}$.

Chemicals and inhibitors. Hispolon was synthesized as previously described and its purity was established on the basis of the spectral $\left({ }^{1} \mathrm{H},{ }^{13} \mathrm{C}\right.$ NMR and mass) data. Hispolon stocks (20 $\mathrm{mM})$ were prepared in dimethylsulphoxide (DMSO) and stored at $-20^{\circ} \mathrm{C}$. TPA and NAC were purchased from Sigma (St. Louis, MO, USA). SB203580 (p38 inhibitor), SP600125 (JNK inhibitor) and LY294002 (AKT inhibitor) were obtained from Calbiochem (San Diego, CA, USA). U0126 (ERK inhibitor) was from Cell Signaling Technology.

Cell viability assay. The effect of hispolon on the viability of MCF-7 cells was evaluated using MTT method. Briefly, cells were grown in 96-well microtiter plates for drug treatment. Following incubation for the indicated times, cells were incubated with MTT $(0.5 \mathrm{mg} / \mathrm{ml})$ for $4 \mathrm{~h}$. The formazan precipitate was dissolved in $150 \mu \mathrm{l} \mathrm{DMSO}$, and the absorbance was detected at $490 \mathrm{~nm}$ with a Model ELX800 microplate reader (Bio-Tek Instruments). Each test was performed in triplicate experiments.

Cell migration assay. The cell migration assay was conducted using Transwell chambers according to the manufacturer's instructions. Briefly, 5x10 $\mathrm{MCF}-7$ cells suspended in $500 \mu \mathrm{l}$ of serum-free medium and seeded into the upper chamber of the inserts. After treatment with different concentrations of hispolon, $750 \mu \mathrm{l}$ of serum-free medium containing $100 \mathrm{ng} / \mathrm{ml}$ of TPA was added to the bottom wells as a chemoattractant. The chambers were incubated at $37^{\circ} \mathrm{C}$ for $24 \mathrm{~h}$. After incubation, the filter inserts were removed from the wells and the cells on the upper side of the filter were removed using cotton swabs. Cells that had invaded to the underside of the filter were first fixed with methanol (15 min), and then stained with $2 \%$ ethanol containing $0.2 \%$ crystal violet powder $(15 \mathrm{~min})$. After being dried, the stained cells were enumerated under light microscope at $\mathrm{x} 10$ objective.
Intracellular ROS detection. DCFH-DA is a cell-permeable fluorescent dye specific for ROS and is used to detect intracellular ROS levels. Cells were seeded in 12-well plates and were cultured in serum-free medium for $24 \mathrm{~h}$, and then treated with $100 \mathrm{ng} / \mathrm{ml}$ TPA for different periods of time. At the designated time points, cells were washed twice with phosphate-buffered saline (PBS) and fixed with $10 \%$ formaldehyde for $10 \mathrm{~min}$. Intracellular ROS levels were assessed by staining with DCFH-DA $(5 \mu \mathrm{M})$ for $30 \mathrm{~min}$ at $37^{\circ} \mathrm{C}$. Fluorescent images were captured using an inverted fluorescence microscope (Nikon Eclipse TE300; Nikon, Melville, NY, USA).

Western blotting. Total cell extracts were prepared using an M-PER mammalian protein extraction reagent kit (Pierce) according to the manufacturer's instructions. The protein concentration of each extract was determined by the Bradford assay. Cell extracts were separated by electrophoresis on 6-15\% sodium dodecyl sulfate-polyacrylamide gel (SDS-PAGE) and then transferred to nitrocellulose membranes. The membranes were probed with a primary antibody followed by a secondary antibody conjugated to horseradish peroxidase. Protein bands on the membranes were detected by enhanced chemiluminescence [Western Lightning (Perkin-Elmer Boston, MA, USA) or SuperSignal West Femto (Pierce, Rockford, IL, USA)].

Statistical analysis. Numerical data are presented as means \pm SD of different determinations. Statistical significance between treatment and control groups was analyzed using Student's t-test. Values of $\mathrm{p}<0.05$ were considered to indicate a statistically significant result.

\section{Results}

TPA downregulates E-cadherin expression through the production of ROS in MCF-7 cells. 12-O-Tetradecanoylphorbol-13-acetate (TPA) is one of the most utilized agents for studying the mechanisms of carcinogenesis. To characterize the effect of TPA on cell morphology in human breast cancer MCF-7 cells, we treated cells with TPA $(100 \mathrm{ng} / \mathrm{ml})$ for $24 \mathrm{~h}$. As shown in Fig. 1A, treatment with TPA-induced an obvious morphological change, from a cobblestone-like morphology to fibroblastic-spindle shape, which is a typical morphology change in EMT. To further confirm the presence of EMT and investigate the molecular mechanism by which TPA-induced the morphological change, we investigated the expression of E-cadherin which plays a key role during EMT. Western blot analysis showed that TPA downregulated total E-cadherin protein levels in a dose- and time-dependent manner in MCF-7 cells (Fig. 1B).

DCFH-DA was used to examine the effect of TPA treatment on intracellular ROS production. TPA treatment induced ROS production in a time-dependent manner in MCF-7 cells (Fig. 2A). To confirm the relation of ROS production and E-cadherin expression, cells were pretreated with NAC, an antioxidant reagent. As shown in Fig. 2B, downregulation of E-cadherin induced by TPA was inhibited by pretreating NAC. To further confirm the effect of ROS on E-cadherin expression, MCF-7 cells were treated with exogenous $\mathrm{H}_{2} \mathrm{O}_{2}$. Notably, $\mathrm{H}_{2} \mathrm{O}_{2}$ treatment downregulated E-cadherin protein 


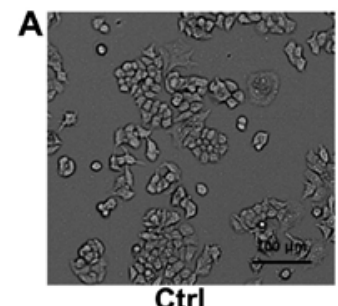

Ctrl

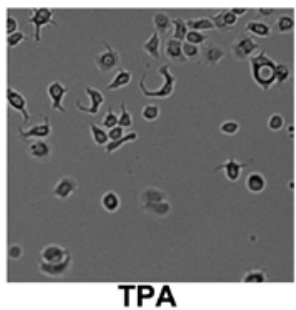

B
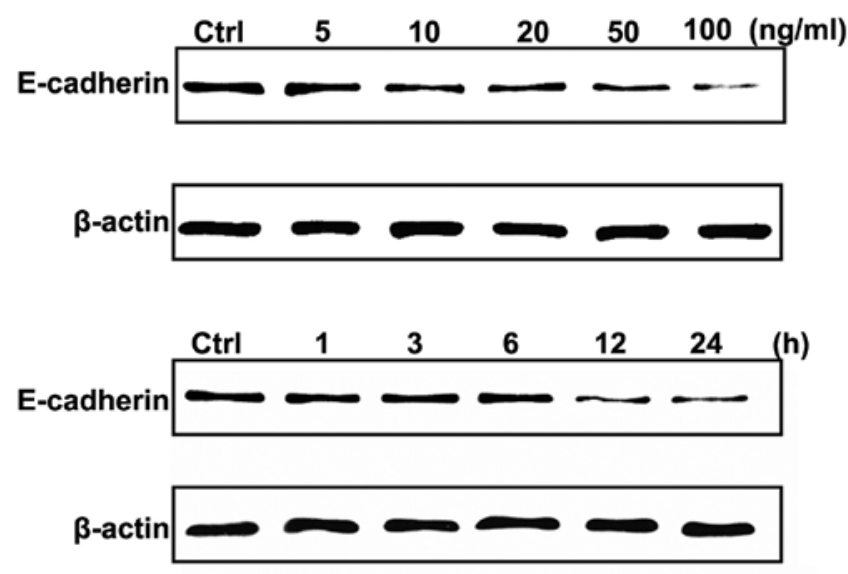

Figure 1. TPA induces morphological changes and downregulates E-cadherin in a dose- and time-dependent manner in MCF-7 breast cancer cells. (A) Cells were treated without (control; Ctrl) or with $100 \mathrm{ng} / \mathrm{ml} \mathrm{TPA}$ for $24 \mathrm{~h}$, and the resultant morphology was microscopically examined. All data presented similar results from three independent experiments. (B) Cells were treated with increasing doses of TPA for $24 \mathrm{~h}$ or with $100 \mathrm{ng} / \mathrm{ml}$ TPA for different durations. Total cellular levels of E-cadherin were analyzed by western blotting.

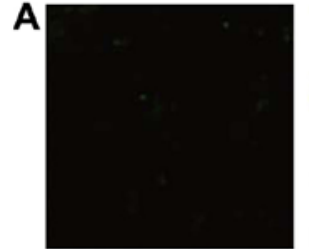

Ctrl

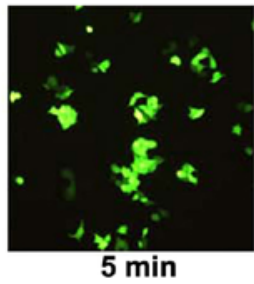

TPA

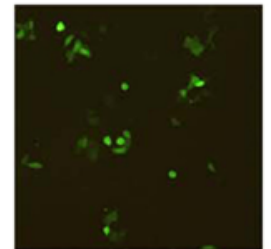

10 min

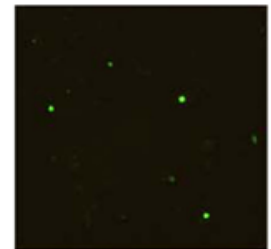

30 min

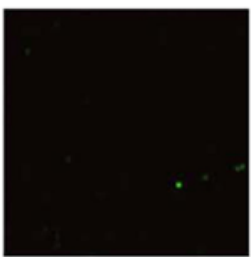

$60 \mathrm{~min}$

B

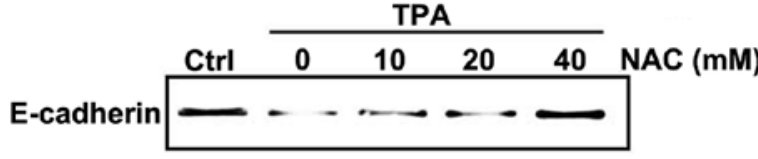

C
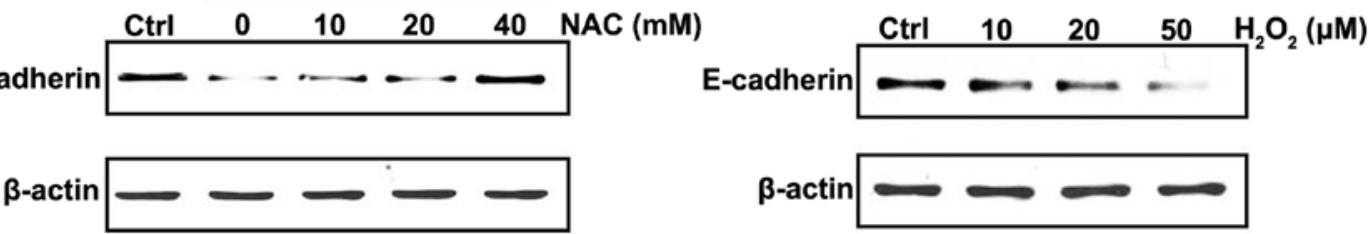

Figure 2. TPA downregulates E-cadherin expression via ROS production. (A) MCF-7 cells were serum starved for $24 \mathrm{~h}$ and treated with or without $100 \mathrm{ng} / \mathrm{ml}$ TPA. At the indicated time points, cells were washed twice with PBS and fixed with $10 \%$ formaldehyde. Intracellular ROS levels were measured by staining with DCFH-DA $(10 \mu \mathrm{M})$, and images were captured using a fluorescence microscope. (B) Cells were pretreated for $3 \mathrm{~h}$ with different doses of NAC, followed by treatment with $100 \mathrm{ng} / \mathrm{ml}$ TPA for $24 \mathrm{~h}$. E-cadherin protein levels were analyzed by western blotting. (C) Cells were treated with different doses of $\mathrm{H}_{2} \mathrm{O}_{2}$ for $24 \mathrm{~h}$ and E-cadherin protein levels were examined by western blotting.

levels in a dose-dependent manner (Fig. 2C). These results suggested that the effect of TPA on E-cadherin in MCF-7 cells was closely related with the production of intracellular ROS.

Slug expression is upregulated by TPA-induced ROS production. To investigate whether TPA downregulated E-cadherin expression by modulating the transcriptional regulation of E-cadherin, we examined the protein levels of E-cadherin transcriptional repressors, Snail and Slug. Treatment with TPA significantly increased Snail and Slug expression in a time-dependent manner (Fig. 3A). To determine whether ROS production was involved in TPA-induced increasing levels of Snail and Slug proteins, cells were pretreated with NAC in the presence of TPA. As shown in Fig. 3B, NAC pretreatment diminished TPA-stimulated Slug levels, whereas the increase in Snail levels were not affected. Notably, exogenous $\mathrm{H}_{2} \mathrm{O}_{2}$ increased both Snail and Slug levels in a different manner compared to TPA (Fig. 3C).

Hispolon inhibits TPA-induced EMT. Hispolon is a natural polyphenol compound isolated from medical fungus. We first evaluated the effect of hispolon on the viability of breast cancer MCF-7 cells. At the concentrations tested, between 5 and $20 \mu \mathrm{M}$, for duration of $24 \mathrm{~h}$, hispolon demonstrated negligible antiproliferative effects on the cells (Fig. 4A). To ascertain that any possible anti-migration effects of hispolon observed was not due to their antiproliferative activities, nonlethal concentrations $(\leq 20 \mu \mathrm{M})$ were used for the following experiments. 

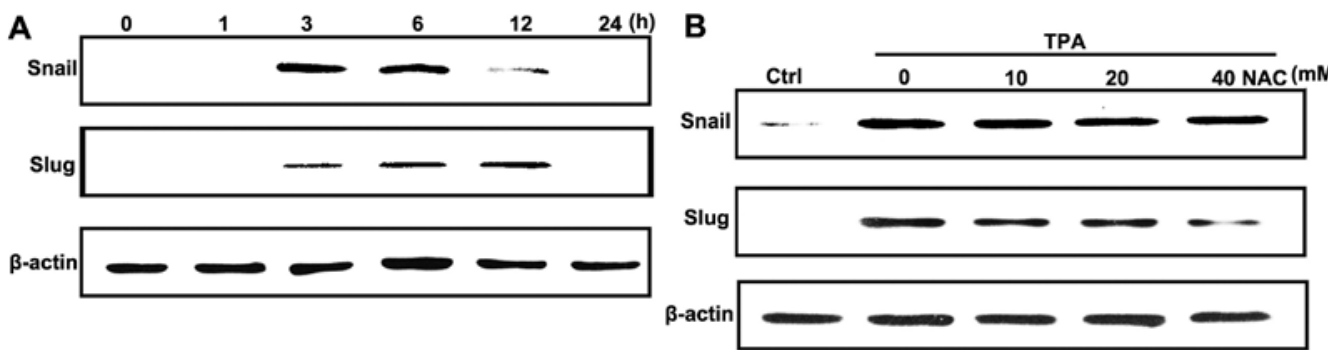

C

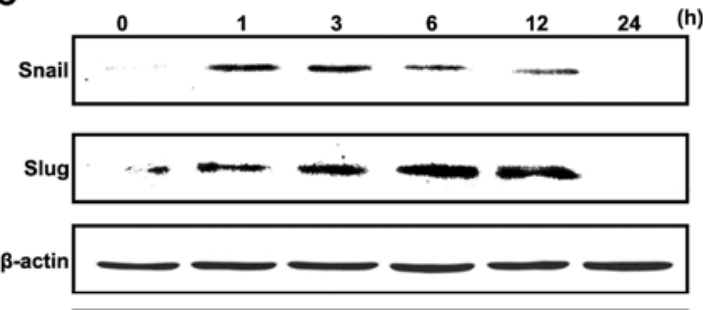

Figure 3. TPA induces Snail and Slug expression through ROS production. (A) Cells were treated with $100 \mathrm{ng} / \mathrm{ml} \mathrm{TPA}$ for various times, and the protein levels of Snail and Slug were analyzed by western blotting. (B) Cells were pretreated for $3 \mathrm{~h}$ with NAC, followed by treatment for $3 \mathrm{~h}$ (Snail) or $12 \mathrm{~h}$ (Slug) with $100 \mathrm{ng} / \mathrm{ml}$ TPA, and protein levels were analyzed by western blotting. (C) Cells were treated with $\mathrm{H}_{2} \mathrm{O}_{2}$ for different times and protein levels of Snail and Slug were examined by western blotting.

\section{A}

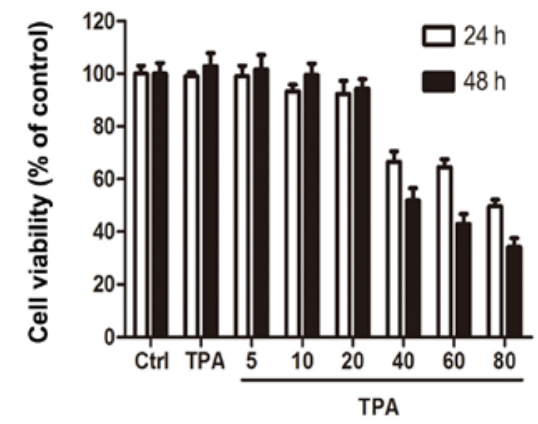

Concentration $(\mu \mathrm{M})$

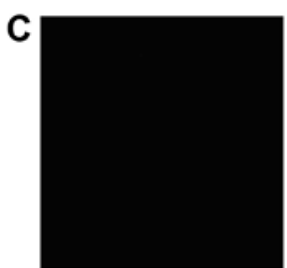

Cirl

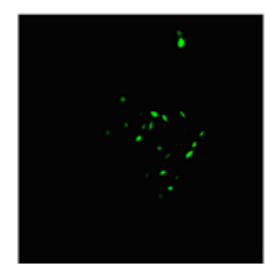

TPA+Hispolon

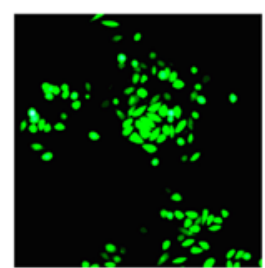

TPA

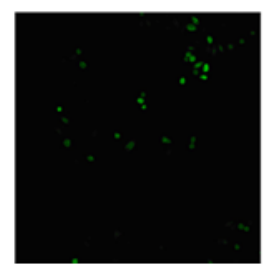

TPA+NAC
B
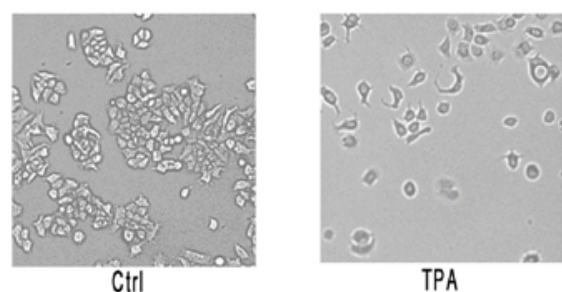

TPA

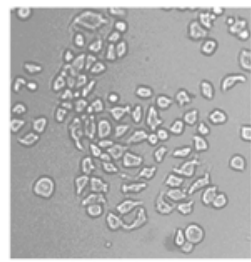

TPA+Hispolon

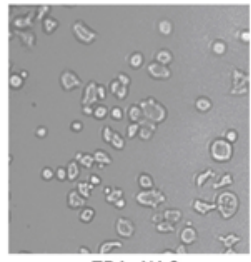

TPA+NAC

D
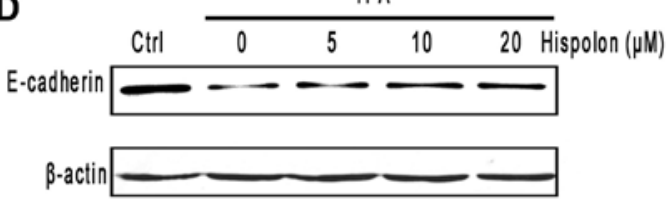

E

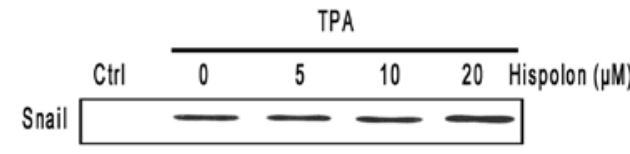

Slug

$\beta$-actin $\longrightarrow-\longrightarrow$

Figure 4. Hispolon inhibits TPA-induced EMT by reducing cellular ROS production at sublethal doses. (A) Effect of hispolon on the viability of MCF-7 cells. Following $24 \mathrm{~h}$ treatment with different doses of hispolon in the presence or absence of $100 \mathrm{ng} / \mathrm{ml}$ TPA, viability of MCF-7 cells was determined using MTT. Data represent mean \pm SD of three independent experiments. (B) TPA-mediated morphological changes were abolished by hispolon. Cells were pretreated with hispolon $(20 \mu \mathrm{M})$ or NAC $(40 \mathrm{mM})$ for $3 \mathrm{~h}$, followed by treatment with $100 \mathrm{ng} / \mathrm{ml}$ TPA for $24 \mathrm{~h}$, and the resultant morphology was examined microscopically. (C) TPA-induced intracellular ROS production was inhibited by hispolon. MCF-7 cells were serum starved for $24 \mathrm{~h}$ and were pretreated with hispolon or NAC for $3 \mathrm{~h}$, followed by treatment with $100 \mathrm{ng} / \mathrm{ml}$ TPA for $5 \mathrm{~min}$. Cells were washed twice with PBS and fixed with $10 \%$ formaldehyde. Intracellular ROS levels were measured by staining with DCFH-DA $(10 \mu \mathrm{M})$, and images were captured using a fluorescence microscope. (D) TPA-mediated downregulation of E-cadherin was abolished by hispolon. Cells were exposed to different doses of hispolon for $3 \mathrm{~h}$ and then were stimulated with $100 \mathrm{ng} / \mathrm{ml}$ of TPA for $24 \mathrm{~h}$. E-cadherin protein levels were examined by western blotting. (E) Cells were pretreated for $3 \mathrm{~h}$ with hispolon, followed by treatment for $3 \mathrm{~h}$ (Snail) or $12 \mathrm{~h}$ (Slug) with $100 \mathrm{ng} / \mathrm{ml} \mathrm{TPA}$, and protein levels were analyzed by western blotting. 

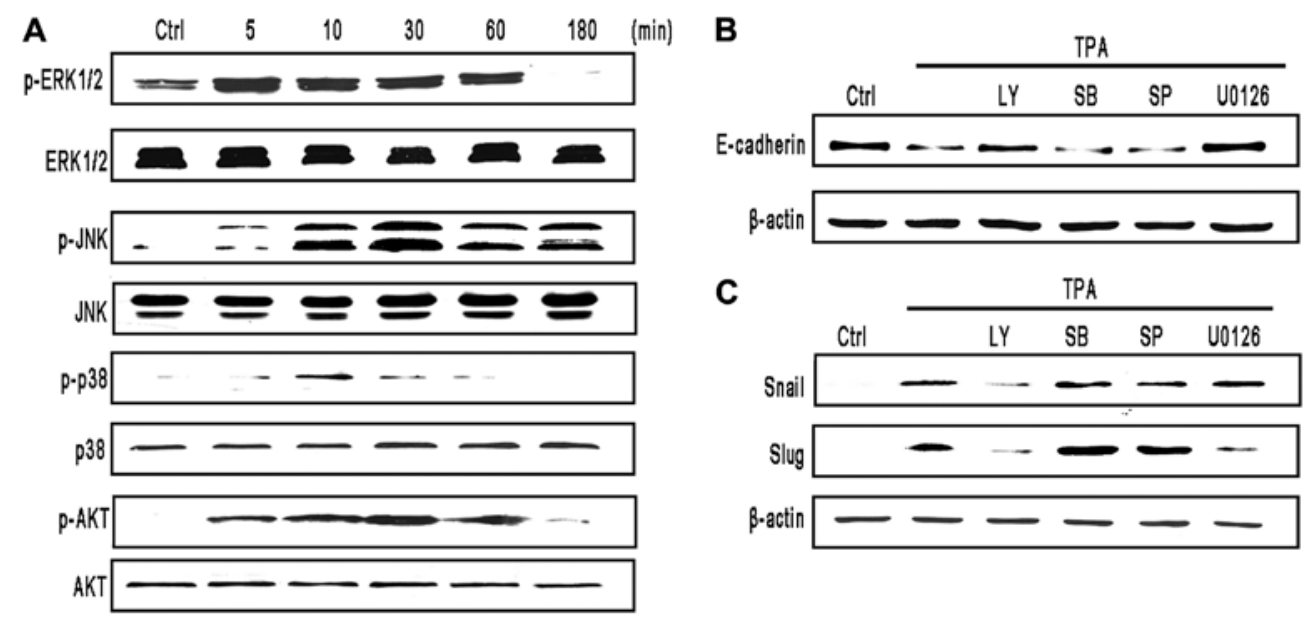

C

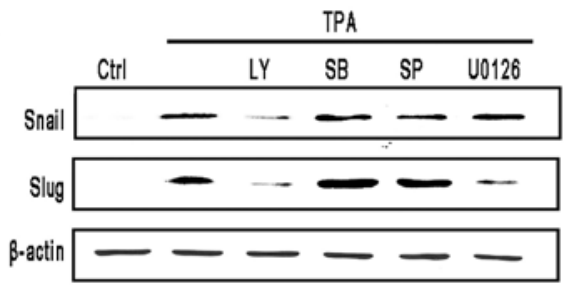

Figure 5. TPA downregulates E-cadherin expression by ERK and AKT signaling pathway. (A) TPA activates the MAPK signaling pathway. Cells were treated with $100 \mathrm{ng} / \mathrm{ml}$ TPA for the indicated durations. Phosphorylation of ERK, p38, JNK and AKT were determined by western blotting using antibodies specific for phosphorylated, activated forms of ERK (p-ERK), p38 (p-p38), JNK (p-JNK) and AKT (p-AKT). Membranes were stripped and reprobed with antibodies to total ERK, p38, JNK and AKT. (B and C) MCF-7 cells were pretreated with selective MAPK pathway inhibitors, LY294002 (LY) (20 $\mu$ M), SB203580 (SB) $(20 \mu \mathrm{M})$, SP600125 (SP) $(20 \mu \mathrm{M})$, U0126 (20 $\mu \mathrm{M})$ for $3 \mathrm{~h}$, followed by treatment with $100 \mathrm{ng} / \mathrm{ml} \mathrm{TPA}$, (B) for $24 \mathrm{~h}$ (E-cadherin) (C) for $3 \mathrm{~h}$ (Snail) or $12 \mathrm{~h}$ (Slug) and protein levels were analyzed by western blotting.

From the morphological aspect, hispolon markedly inhibited the TPA-induced morphologic change. Following treatment with TPA, MCF-7 cells acquired spindle-like cell morphology. Notably, pretreatment with $20 \mu \mathrm{M}$ hispolon significantly inhibited TPA-induced changes in cell morphology (Fig. 4B). To show whether hispolon inhibited the change of cell morphology by expression of E-cadherin, we examined the protein level of E-cadherin by western blotting in dose-response analysis. As shown in Fig. 4D, downregulation of E-cadherin was clearly abolished by hispolon in a dose-dependent manner. Since Snail and Slug are considered to be master regulators of E-cadherin, the protein expression levels of transcription factors were evaluated by western blotting. The Slug expression level was upregulated by TPA stimulation in MCF-7 cells, which was abolished by hispolon in a dose-dependent manner. However, the expression of Snail was not affected by hispolon (Fig. 4E).

To determine whether ROS production was involved in hispolon against TPA-induced EMT, we examined hispolon-mediated cellular ROS level changes. The cells were pretreated with the antioxidant reagent NAC followed by treatment with TPA. Strikingly, the cellular ROS levels were reduced after pretreatment with hispolon (Fig. 4C). As shown in Fig. 4B and C, NAC decreased the intracellular ROS levels and inhibited the morphological change which was induced by treatment of TPA in MCF-7 cells. These results demonstrated that hispolon inhibited TPA-induced EMT through repressing the ROS production.

Hispolon inhibits TPA-induced EMT by activation of ERK. Numerous studies have demonstrated that tumor metastasis originates from abnormal regulation of the activation of intracellular signal molecules such as mitogen-activated protein kinase and tyrosine kinase (MAPK), including ERK, p38, c-Jun N-terminal kinase (JNK) and AKT kinase which are important downstream signaling cascades involved in tumor cell migration. Herein, we examined the expressions

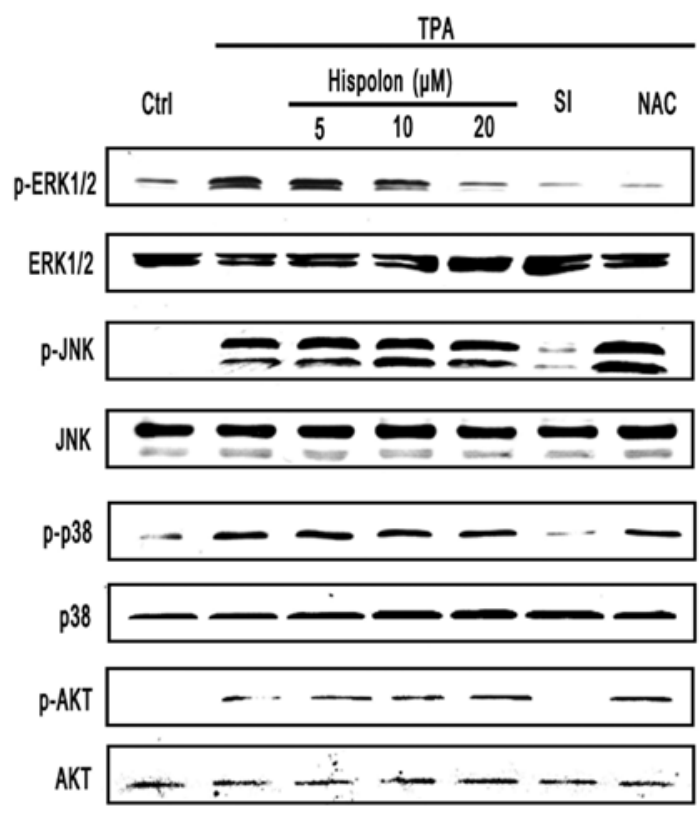

Figure 6. Hispolon inhibits TPA-induced downregulation of E-cadherin by ERK signaling pathway. Cells were pretreated with different doses of hispolon, NAC or selective signal pathway inhibitors (SI) for $3 \mathrm{~h}$, followed by treatment with $100 \mathrm{ng} / \mathrm{ml}$ TPA. Phosphorylation of ERK, p38, JNK and AKT was analyzed by western blotting.

of phospho-AKT, AKT, phospho-MAPK and MAPK expression in MCF-7 cells. The phosphorylation levels of AKT and MAPK were increased by TPA time-dependently. A timecourse analysis showed that the phosphorylation levels of AKT and MAPK peaked at 5-30 min after TPA stimulation and gradually recovered to the baseline values $3 \mathrm{~h}$ later (Fig. 5A). These results indicated that AKT and MAPK signaling pathways were actually capable of being activated in response to TPA in MCF-7 cells.

To assess whether MAPK and AKT activation were involved in TPA-induced EMT, cells were pretreated with 

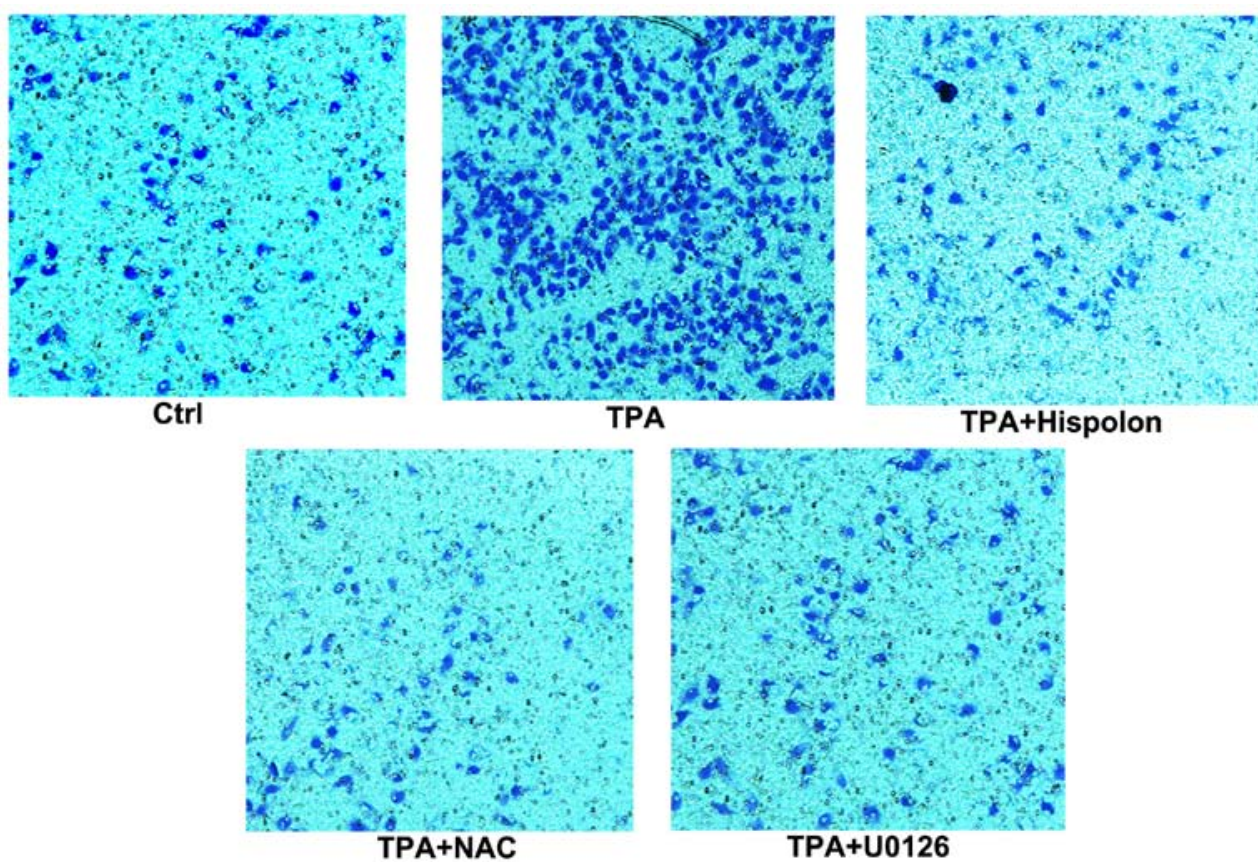

Figure 7. Hispolon inhibits TPA-induced cell migration. Cells were pretreated for $3 \mathrm{~h}$ with hispolon, NAC, U0126 and seeded into Transwell inserts and cultured by treatment with $100 \mathrm{ng} / \mathrm{ml}$ TPA for $24 \mathrm{~h}$. The migrating cells were stained with crystal violet, and the resultant morphology was examined microscopically. All the data presented similar results from three independent experiments.

special kinase inhibitors. Notably, we found that the AKT inhibitor LY294002 and the ERK inhibitor U0126 diminished the inhibitory effects of TPA on E-cadherin protein levels, but the p38 MAPK and JNK inhibitor did not (Fig. 5B). Furthermore, as shown in Fig. 5C, treatment with the ERK inhibitor U0126 diminished the upregulation of TPA-induced Slug. Treatment with the AKT inhibitor LY294002 diminished the upregulation of TPA-induced Snail and Slug. To some extent, ERK and AKT kinases were involved in TPA-induced EMT.

To investigate whether ROS production, ERK and AKT activation, and the subsequent upregulation of transcription factors were involved in hispolon inhibiting TPA-induced EMT, cells were pretreated with hispolon. Notably, we found that hispolon markedly diminished TPA-induced ERK phosphorylation but did not affect TPA-induced phosphorylation of p38 MAPK, JNK and AKT (Fig. 6). Notably, treatment with antioxidant NAC showed similar phenomenon (Fig. 6). Taken together, these results suggested that hispolon downregulated Slug expression via ERK signaling by inhibiting the production of intracellular ROS.

Hispolon inhibits TPA-induced cell migration. Since hispolon inhibited the TPA-induced EMT in MCF-7 cells, we next examined whether the inhibitory effect of hispolon on EMT led to an inhibition of cellular migration in MCF-7 cells. As shown in Fig. 7, migration assay revealed that hispolon reduced TPA-mediated cellular migration. U0126 and NAC inhibited TPA-induced cell migration in MCF-7 cells and to the same extent by hispolon. These results suggested that hispolon actually inhibits the cellular migration phenotype of the EMT in MCF-7 cells. It is assumed that the inhibitory activity of hispolon on the cellular migration phenotype is due to its inhibitory effect of ROS-ERK signaling pathway.
Taken together, these results indicated that hispolon inhibits the TPA-induced EMT, and is characterized by E-cadherin downregulation, morphologic changes and an increase in the cellular migrating phenotype by inhibiting ROS/ERK/Slug/Ecadherin pathway in MCF-7 cells.

\section{Discussion}

Metastasis is a major obstacle for cancer therapy and is a primary cause of mortality in many cancer types, including breast cancer. TPA is a well-known tumor promoter and exhibits many biological effects by altering gene expression. Previous studies revealed that TPA was a potential inducer of tumor invasion/migration in breast cancer cells and EMT in human prostate cancer $\mathrm{ARCaP}_{\mathrm{E}}$ cells $(27,28)$. Additionally, TPA has been shown to downregulate E-cadherin expression in human cancer cells, resulting in tumor metastasis $(29,30)$. Moreover, studies showed that ROS are essential mediators of TPA-induced cell migration and invasion $(20,31)$. However, the specific role of ROS in the downregulation of E-cadherin expression caused by TPA signaling remains to be elucidated. In the present study, we reported that ROS-mediated TPA-induced E-cadherin downregulation and cell migration. ROS exerted their effects via activating ERK and increasing Slug expression. In addition, our studies suggested that hispolon, a natural polyphenol compound, could inhibit TPA-induced cell migration through ROS/ERK/Slug/Ecadherin signaling pathway.

ROS generation is induced by various growth factors, cytokines and tumor promoters $(17,18,32)$. The contribution of an elevation in ROS to carcinogenesis was detected in several different types of cancer cells, and the ROS-mediated signaling cascade in tumor metastasis was highlighted. 
However, the importance of ROS generation in TPA-induced migration of breast cancer cells is still undefined. In the present study, increasing ROS generation followed by cell migration, MAPK activation and loss of E-cadherin expression were observed in TPA-treated MCF-7 breast cells, and they were blocked by addition of the antioxidant NAC through reduction in ROS. These results suggest that the production of ROS may be a critical mediator in TPA-induced EMT, and TPA-induced ROS generation was an initial event in the progression of breast cancer metastasis. Notably, the time course of exogenous $\mathrm{H}_{2} \mathrm{O}_{2}$-induced Slug expression was significantly different from that of TPA. Moreover, NAC abolished TPA-induced expression of Slug in MCF-7 cells, but treatment with exogenous $\mathrm{H}_{2} \mathrm{O}_{2}$ increased both expression of Snail and Slug. These results indicated that the functional consequences of TPA-induced endogenous ROS signaling differed from those of exogenous $\mathrm{H}_{2} \mathrm{O}_{2}$ treatment. Previous research showed that NF- $\kappa \mathrm{B}$ rather than ROS play a more important role in the TNF- $\alpha$-induced EMT of MCF-7 cells (33). However, our present study suggested EMT transition was mainly due to the production of cellular ROS stimulated by TPA.

Loss of E-cadherin gene expression, which is the hallmark of epithelial-mesenchymal transition (EMT), is mainly due to upregulation of E-cadherin repressors such as Snail and Slug. Indeed, ectopic expression of Snail or Slug in SKOV3 cells results in EMT associated enhanced motility, invasiveness and tumorigenicity (34). In the present study, we found that TPA could induce Snail and Slug expression by producing intracellular ROS. However, treatment with the antioxidant agent NAC totally blocked ROS production but only partially abolished the TPA-induced EMT and cell migration and did not inhibit TPA-induced Snail expression. Thus, we predicted that other ROS independent pathways may contribute to Snail induction and mediate TPA-induced E-cadherin downregulation. Additionally, we also found hispolon and NAC abolished TPA-induced expression of Slug, but not Snail in MCF-7 cells. Although Slug is thought to function in a redundant manner with Snail, several recent studies suggested unique functions of Slug. i) Slug was essential for Notch1:Jagged 1-mediated EMT, tumor growth and metastasis (35); ii) Slug expression was correlated with poor breast cancer prognosis (36); iii) Slug, but not Snail or Twist was expressed in ES cells and was part of the ES cell signature activated in several cancer cells (37); iv) Slug but not Snail expression, was linked to ductal development in the breast including tubule maintenance or growth within invasive ductal carcinoma (38). These observations along with the results of the present study highlighted critical role of Slug in breast cancer metastasis.

MAPK and AKT cascades are major signaling pathways which can drive the metastasis of tumor cells (39). It was demonstrated that increased ROS levels may enhance MAPK activities in the malignant progression of cancer cells $(17,19)$. However, the role of ROS in MAPK activation induced cell migration is not clear. In the present study, TPA treatment significantly increased ERK, p38 and JNK expression in breast cancer cells. However, only TPA-induced activation of ERK was inhibited by NAC treatment. In addition, E-cadherin inhibition by U0126 significantly reduced TPA-induced breast cancer cell migration. Taken together, our results indicated that ROS-dependent ERK activation was involved in TPA-induced E-cadherin downregulation and cell invasion in breast cancer cells. AKT kinase is a convergence point for multiple extracellular and other upstream signals, functioning as a master switch to generate a plethora of intracellular signals and responses. Downstream targets of AKT are thought to be involved in survival, growth, metastasis and metabolic-related pathways $(40,41)$. Activation of AKT signaling has been detected in cells undergoing EMT (42). In the present study, phosphorylation of AKT was not inhibited by pretreatment with hispolon. The AKT kinase inhibitor LY294002 prevented TPA-induced upregulation of Snail or Slug, or downregulation of E-cadherin, suggesting the AKT pathway was not involved in the antimetastasis effect of hispolon. These results indicated that a different signal pathway may be involved in the EMT progression, and ERK pathway was the major mediator in MCF-7 cells treated by hispolon.

For centuries, people have been harnessing the power of nature to provide medicinal solutions to various diseases. In particular, rich sources of natural compounds isolated from plants have potential anticancer activities. Various well-known naturally occurring agents, such as resveratrol (43), quercetin (44), curcumin (45) and gingerol $(46,47)$ have been demonstrated to exert inhibitory effects on cancer cell invasion and metastasis. Hispolon, isolated from medical fungus, is a natural polyphenol compound with low toxicity, have antiviral, antiproliferative and immunomodulatory activities $(24,25,48)$. Moreover, numerous studies have shown the antiproliferation activity of hispolon in many types of human cancers. Our previous research showed hispolon could inhibit TPA-induced migration and invasion of MDA-MB-231 cells by reducing MMP-9 secretion and expression, mainly through the NF- $\mathrm{KB}$ signaling pathway (49). In the present study, we confirmed that hispolon can inhibit the migration of MCF-7, breast cancer cells by a completely different mechanism. Previous literature show ER signaling may globally regulate the EMT program (50) and loss of ER may change the expression profile of specific matrix macromolecules (51). Moreover, hispolon inhibited cell growth through modulation of ER in estrogenpositive breast cancer cells (52). Regarding different ER status of the two breast cancer cell types involved in our research, the different mechanism of anti-migration of hispolon may depend on the different ER status. Although further studies are needed to establish the exact signal pathway, our results taken together strengthen the potential of hispolon as a multitarget drug in anticancer therapy.

In the present study, we demonstrated that hispolon inhibited migration of breast cancer MCF-7 cells through E-cadherin. Hispolon could downregulate Slug by inhibiting ERK signaling, thereby inhibiting the TPA-mediated EMT in breast cancer cells. Our results provided new insight into the mechanisms of hispolon inhibition of cancer cell metastasis and suggested that hispolon could be a potential agent for treatment of breast cancers.

\section{Acknowledgements}

The present study was supported by the following grants: the Natural Science Foundation of Zhejiang Province (grant no. LQ14H160016), and the Zhejiang Province Program for the Cultivation of High-level Innovative Health Talents (2012). 


\section{References}

1. Jemal A, Center MM, DeSantis C and Ward EM: Global patterns of cancer incidence and mortality rates and trends. Cancer Epidemiol Biomarkers Prev 19: 1893-1907, 2010.

2. Weigelt B, Hu Z, He X, Livasy C, Carey LA, Ewend MG, Glas AM, Perou CM and Van't Veer LJ: Molecular portraits and 70 -gene prognosis signature are preserved throughout the metastatic process of breast cancer. Cancer Res 65: 9155-9158, 2005.

3. Tsuji T, Ibaragi S and Hu GF: Epithelial-mesenchymal transition and cell cooperativity in metastasis. Cancer Res 69: 7135-7139, 2009.

4. Polyak K and Weinberg RA: Transitions between epithelial and mesenchymal states: Acquisition of malignant and stem cell traits. Nat Rev Cancer 9: 265-273, 2009.

5. Miyoshi J and Takai Y: Structural and functional associations of apical junctions with cytoskeleton. Biochim Biophys Acta 1778: 670-691, 2008

6. Voulgari A and Pintzas A: Epithelial-mesenchymal transition in cancer metastasis: Mechanisms, markers and strategies to overcome drug resistance in the clinic. Biochim Biophys Acta 1796: 75-90, 2009

7. Doyle S, Evans AJ, Rakha EA, Green AR and Ellis IO: Influence of E-cadherin expression on the mammographic appearance of invasive nonlobular breast carcinoma detected at screening. Radiology 253: 51-55, 2009.

8. Batlle E, Sancho E, Francí C, Domínguez D, Monfar M, Baulida J and García De Herreros A: The transcription factor snail is a repressor of E-cadherin gene expression in epithelial tumour cells. Nat Cell Biol 2: 84-89, 2000.

9. Comijn J, Berx G, Vermassen P, Verschueren K, van Grunsven L, Bruyneel E, Mareel M, Huylebroeck D and van Roy F: The twohanded $\mathrm{E}$ box binding zinc finger protein SIP1 downregulates E-cadherin and induces invasion. Mol Cell 7: 1267-1278, 2001.

10. Peinado H, Olmeda D and Cano A: Snail, Zeb and bHLH factors in tumour progression: An alliance against the epithelial phenotype? Nat Rev Cancer 7: 415-428, 2007.

11. Wu WS: The signaling mechanism of ROS in tumor progression Cancer Metastasis Rev 25: 695-705, 2006.

12. Wu WS, Wu JR and Hu CT: Signal cross talks for sustained MAPK activation and cell migration: The potential role of reactive oxygen species. Cancer Metastasis Rev 27: 303-314, 2008.

13. Boonstra J and Post JA: Molecular events associated with reactive oxygen species and cell cycle progression in mammalian cells. Gene 337: 1-13, 2004.

14. Hu CT, Wu JR, Cheng CC, Wang S, Wang HT, Lee MC, Wang LJ, Pan SM, Chang TY and Wu WS: Reactive oxygen species-mediated PKC and integrin signaling promotes tumor progression of human hepatoma HepG2. Clin Exp Metastasis 28: 851-863, 2011

15. Wang Z, Li Y and Sarkar FH: Signaling mechanism(s) of reactive oxygen species in epithelial-mesenchymal transition reminiscent of cancer stem cells in tumor progression. Curr Stem Cell Res Ther 5: 74-80, 2010.

16. Hwang YS, Jeong M, Park JS, Kim MH, Lee DB, Shin BA Mukaida N, Ellis LM, Kim HR, Ahn BW, et al: Interleukin-lbeta stimulates IL-8 expression through MAP kinase and ROS signaling in human gastric carcinoma cells. Oncogene 23: 6603-6611, 2004.

17. Lin CW, Yang LY, Shen SC and Chen YC: IGF-I plus E2 induces proliferation via activation of ROS-dependent ERKs and JNKs in human breast carcinoma cells. J Cell Physiol 212: 666-674, 2007.

18. Binker MG, Binker-Cosen AA, Richards D, Oliver B and CosenBinker LI: EGF promotes invasion by PANC-1 cells through Rac1/ROS-dependent secretion and activation of MMP-2. Biochem Biophys Res Commun 379: 445-450, 2009.

19. Lee KH and Kim JR: Reactive oxygen species regulate the generation of urokinase plasminogen activator in human hepatoma cells via MAPK pathways after treatment with hepatocyte growth factor. Exp Mol Med 41: 180-188, 2009.

20. Wu WS, Tsai RK, Chang CH, Wang S, Wu JR and Chang YX Reactive oxygen species mediated sustained activation of protein kinase $\mathrm{C}$ alpha and extracellular signal-regulated kinase for migration of human hepatoma cell Hepg2. Mol Cancer Res 4 747-758, 2006

21. Mori K, Shibanuma M and Nose K: Invasive potential induced under long-term oxidative stress in mammary epithelial cells. Cancer Res 64: 7464-7472, 2004.
22. Chen W, He FY and Li YQ: The apoptosis effect of hispolon from Phellinus linteus (Berkeley \& Curtis) Teng on human epidermoid KB cells. J Ethnopharmacol 105: 280-285, 2006.

23. Mo S, Wang S, Zhou G, Yang Y, Li Y, Chen X and Shi J: Phelligridins C-F: Cytotoxic pyrano[4,3-c][2]benzopyran1,6-dione and furo[3,2-c]pyran-4-one derivatives from the fungus Phellinus igniarius. J Nat Prod 67: 823-828, 2004.

24. Chen W, Zhao Z, Li L, Wu B, Chen SF, Zhou H, Wang Y and Li YQ: Hispolon induces apoptosis in human gastric cancer cells through a ROS-mediated mitochondrial pathway. Free Radic Biol Med 45: 60-72, 2008.

25. Huang GJ, Deng JS, Huang SS and Hu ML: Hispolon induces apoptosis and cell cycle arrest of human hepatocellular carcinoma Hep3B cells by modulating ERK phosphorylation. J Agric Food Chem 59: 7104-7113, 2011.

26. Huang GJ, Yang CM, Chang YS, Amagaya S, Wang HC, Hou WC, Huang SS and Hu ML: Hispolon suppresses SK-Hep1 human hepatoma cell metastasis by inhibiting matrix metalloproteinase-2/9 and urokinase-plasminogen activator through the PI3K/Akt and ERK signaling pathways. J Agric Food Chem 58 9468-9475, 2010.

27. Park SY, Kim YH, Kim Y and Lee SJ: Frondoside A has an antiinvasive effect by inhibiting TPA-induced MMP-9 activation via $\mathrm{NF}-\kappa \mathrm{B}$ and AP-1 signaling in human breast cancer cells. Int J Oncol 41: 933-940, 2012.

28. Noh EM, Lee YR, Hur H and Kim JS: Radix clematidis extract inhibits TPA-induced MMP-9 expression by suppressing NF- $\kappa \mathrm{B}$ activation in MCF-7 human breast cancer cells. Mol Med Rep 4: 879-883, 2011.

29. Wen-Sheng W: ERK signaling pathway is involved in $\mathrm{p} 15^{\mathrm{INK} 4 \mathrm{~b}} /$ p16 ${ }^{\text {INK4a }}$ expression and HepG2 growth inhibition triggered by TPA and Saikosaponin $a$. Oncogene 22: 955-963, 2003.

30. He H, Davidson AJ, Wu D, Marshall FF, Chung LW, Zhau HE, He D and Wang R: Phorbol ester phorbol-12-myristate-13-acetate induces epithelial to mesenchymal transition in human prostate cancer ARCaP ${ }_{\mathrm{E}}$ cells. Prostate 70: 1119-1126, 2010.

31. Radisky DC, Levy DD, Littlepage LE, Liu H, Nelson CM, Fata JE, Leake D, Godden EL, Albertson DG, Nieto MA, et al: Raclb and reactive oxygen species mediate MMP-3-induced EMT and genomic instability. Nature 436: 123-127, 2005.

32. Traore K, Sharma RB, Burek CL and Trush MA: Role of ROS and MAPK in TPA-induced ICAM-1 expression in the myeloid ML-1 cell line. J Cell Biochem 100: 1010-1021, 2007.

33. Dong R, Wang Q, He XL, Chu YK, Lu JG and Ma QJ: Role of nuclear factor kappa $\mathrm{B}$ and reactive oxygen species in the tumor necrosis factor-alpha-induced epithelial-mesenchymal transition of MCF-7 cells. Braz J Med Biol Res 40: 1071-1078, 2007.

34. Kurrey NK, K A and Bapat SA: Snail and Slug are major determinants of ovarian cancer invasiveness at the transcription level. Gynecol Oncol 97: 155-165, 2005.

35. Leong KG, Niessen K, Kulic I, Raouf A, Eaves C, Pollet I and Karsan A: Jagged1-mediated Notch activation induces epithelialto-mesenchymal transition through Slug-induced repression of E-cadherin. J Exp Med 204: 2935-2948, 2007.

36. Martin TA, Goyal A, Watkins G and Jiang WG: Expression of the transcription factors snail, slug, and twist and their clinical significance in human breast cancer. Ann Surg Oncol 12: 488-496, 2005

37. Ben-Porath I, Thomson MW, Carey VJ, Ge R, Bell GW, Regev A and Weinberg RA: An embryonic stem cell-like gene expression signature in poorly differentiated aggressive human tumors. Nat Genet 40: 499-507, 2008

38. Côme C, Magnino F, Bibeau F, De Santa Barbara P, Becker KF, Theillet $\mathrm{C}$ and Savagner P: Snail and slug play distinct roles during breast carcinoma progression. Clin Cancer Res 12: 5395-5402, 2006

39. Hour MJ, Tsai SC, Wu HC, Lin MW, Chung JG, Wu JB, Chiang JH, Tsuzuki $M$ and Yang JS: Antitumor effects of the novel quinazolinone MJ-33: Inhibition of metastasis through the MAPK, AKT, NF- $\kappa$ B and AP-1 signaling pathways in DU145 human prostate cancer cells. Int J Oncol 41: 1513-1519, 2012

40. Phung TL, Ziv K, Dabydeen D, Eyiah-Mensah G, Riveros M, Perruzzi C, Sun J, Monahan-Earley RA, Shiojima I, Nagy JA, et al: Pathological angiogenesis is induced by sustained Akt signaling and inhibited by rapamycin. Cancer Cell 10: 159-170, 2006.

41. Grille SJ, Bellacosa A, Upson J, Klein-Szanto AJ, van Roy F, Lee-Kwon W, Donowitz M, Tsichlis PN and Larue L: The protein kinase Akt induces epithelial mesenchymal transition and promotes enhanced motility and invasiveness of squamous cell carcinoma lines. Cancer Res 63: 2172-2178, 2003. 
42. Larue L and Bellacosa A: Epithelial-mesenchymal transition in development and cancer: Role of phosphatidylinositol 3' kinase/ AKT pathways. Oncogene 24: 7443-7454, 2005.

43. Woo JH, Lim JH, Kim YH, Suh SI, Min DS, Chang JS, Lee YH, Park JW and Kwon TK: Resveratrol inhibits phorbol myristate acetate-induced matrix metalloproteinase-9 expression by inhibiting JNK and PKC delta signal transduction. Oncogene 23: 1845-1853, 2004

44. Lin CW, Hou WC, Shen SC, Juan SH, Ko CH, Wang LM and Chen YC: Quercetin inhibition of tumor invasion via suppressing PKC delta/ERK/AP-1-dependent matrix metalloproteinase-9 activation in breast carcinoma cells. Carcinogenesis 29: $1807-1815,2008$.

45. Woo MS, Jung SH, Kim SY, Hyun JW, Ko KH, Kim WK and Kim HS: Curcumin suppresses phorbol ester-induced matrix metalloproteinase-9 expression by inhibiting the PKC to MAPK signaling pathways in human astroglioma cells. Biochem Biophys Res Commun 335: 1017-1025, 2005.

46. Lee HS, Seo EY, Kang NE and Kim WK: [6]-Gingerol inhibits metastasis of MDA-MB-231 human breast cancer cells. J Nutr Biochem 19: 313-319, 2008.

47. Yagihashi S, Miura Y and Yagasaki K: Inhibitory effect of gingerol on the proliferation and invasion of hepatoma cells in culture. Cytotechnology 57: 129-136, 2008.
48. Lu TL, Huang GJ, Lu TJ, Wu JB, Wu CH, Yang TC, Iizuka A and Chen YF: Hispolon from Phellinus linteus has antiproliferative effects via MDM2-recruited ERK1/2 activity in breast and bladder cancer cells. Food Chem Toxicol 47: 2013-2021, 2009.

49. Sun YS, Zhao Z and Zhu HP: Hispolon inhibits TPA-induced invasion by reducing MMP-9 expression through the NF- $\kappa \mathrm{B}$ signaling pathway in MDA-MB-231 human breast cancer cells. Oncol Lett 10: 536-542, 2015.

50. Al Saleh S, Al Mulla F and Luqmani YA: Estrogen receptor silencing induces epithelial to mesenchymal transition in human breast cancer cells. PLoS One 6: e20610, 2011.

51 Bouris P, Skandalis SS, Piperigkou Z, Afratis N, Karamanou K, Aletras AJ, Moustakas A, Theocharis AD and Karamanos NK: Estrogen receptor alpha mediates epithelial to mesenchymal transition, expression of specific matrix effectors and functional properties of breast cancer cells. Matrix Biol 43: 42-60, 2015.

52. Jang EH, Jang SY, Cho IH, Hong D, Jung B, Park MJ and Kim JH: Hispolon inhibits the growth of estrogen receptor positive human breast cancer cells through modulation of estrogen receptor alpha. Biochem Biophys Res Commun 463: 917-922, 2015. 